\title{
The Legal Status of Religious Minorities in the Euro-Mediterranean World (RELMIN)
}

\author{
John Tolan*
}

One of the key challenges facing Europe since the end of the Second World War has been to confirm and protect the rights of minority religious groups: Jews in particular, but also Catholics or Protestants (in countries where one or the other group is a minority) and members of other religions who have immigrated into the European Union: Muslims, Buddhists, Hindus, Sikhs and others. The freedom to practice one's religion is a fundamental right inscribed in the laws of the Union and of its member states. Yet in practice, religious expression is perceived differently in various member states and by the members of the diverse religious communities that cohabit in those states. The wearing of a Sikh Turban, a Catholic Holy Week procession, or the call of a muezzin issuing forth from a loudspeaker atop a minaret: each such public expression of religion poses a series of questions involving distinctions between public and private spheres, between religious and cultural symbols, between the identities of religious communities and national polities. The situation is complicated by two contrasting but not mutually exclusive phenomena: an increasing secularization of European societies and a reaffirmation of religious identities. While the broad principles of religious freedom are universally acknowledged, the contours of that freedom in the daily lives of Europeans of all religions (or without religion) vary from one member state to another and are frequently subjects of debate and polemics.

The issues of religious diversity and of the regulation of pluralistic European societies are not new. On the contrary, religious diversity in Europe is grounded in the practice of Christian and Muslim states of the European Middle Ages. In the Christian Roman Empire of the fifth and sixth centuries, emperors banned paganism yet allowed Jews limited freedoms, creating a protected but subordinate status for the empire's Jewish subjects. In the wake of the Muslim conquests of much of the former Roman/Byzantine Empire, Muslim rulers accorded to Jews and Christians the status of dhimmis $^{1}$, protected minorities that enjoyed broad religious freedoms and judicial autonomy, but whose social and political status was inferior to that of Muslims. In Christian kingdoms of medieval Europe, Jews (and in some cases Muslims) were accepted as subordinate minorities who could maintain their synagogues and mosques and openly practice their religions. Towards the end of the Middle Ages, the status of these religious minorities became increasingly precarious in many European states: minorities faced violence and often expulsion: this is the case for Christians and Jews in Almohad Spain (twelfth and thirteenth centuries), for Jews in many medieval and early modern states, and for Muslims in Sicily (thirteenth century) and Spain (fifteenth and sixteenth centuries).

* Correspondance details: Professor John Tolan, ERC programme RELMIN, Maison des Sciences de l'Homme Ange Guépin, 5 Allée Jacques Berque, BP 12105, 44021 Nantes cedex 1, email: John.Tolan@univ-nantes.fr.

1 The Arabic transliteration follows the guidelines of UNGEGN (United Nations Group of Experts on Geographical Names (1972), cf. http://www.eki.ee/wgrs/rom1_ar.pdf (retrieved 10 June 2015). 


\section{A rich and diverse corpus of legal texts dealing with religious minorities}

The legal status of these minorities in European societies, precarious as it at times proved to be, was grounded in fundamental legal and sacred texts and in the traditions of learned commentaries to those texts. A number of imperial laws concerning Jews were promulgated in the fourth and fifth centuries and subsequently were reissued in the Codex Theodosianus promulgated by Theodosius II in 438 . Various laws decree protection of synagogues, respect for the Sabbath (Jews may not be summoned to court on a Saturday), etc. Moreover, a hierarchy of Jewish officials was recognized and given, quite explicitly, the same privileges as the high officials of the Christian church, creating what Amnon Linder has called a Jewish Church $\iota^{2}$. It has often been posited that legal restrictions on Jews are driven by theological considerations. A so-called `Augustinian doctrine r of Judaism relegated Jews to a protected but subordinated social and legal status. In various works, Augustine addresses the role of Jews in Christian society. In the City of God, ${ }^{3}$ he explains that the Jews who put Jesus to death and failed to believe in him were in consequence crushed by the Romans and sent into exile among the nations. Since they are found everywhere, they serve as witnesses, >living letters of the law : proof in the flesh both of the truth of the scriptures which they preserve in the original Hebrew and of the humiliation meted out by Christ to those of his people who refuse to recognize Him as their Lord. While Christian heretics (such as the Donatists) should be compelled to conform to the Catholic faith, Jews should be allowed to live in peace among Christians. They preserve in error the ancient covenant and through their error, and their subservient place in Christian society, serve as unwitting witnesses to the superior truth of Christianity. Moreover, the Jews will, of their own will, massively convert to Christianity at the end of time: this, indeed, will be one of the signs that the end is near. For Jean Juster, the 4th- and 5th-century emperors translated this theological vision into a legal programme, creating a protected and inferior legal and social status for Jews in a now Christian Roman Empire. ${ }^{4}$ Yet in fact, as Capucine Nemo-Pekelman has shown, these Christian emperors are in no way establishing a coherent, theologically centred Jewry law: rather their laws are more often than not reacting to specific situations at the request of various individuals-sometimes bishops or imperial officials, sometimes Jews. ${ }^{5}$ When the jurists working for Theodosius II codify these laws, they do indeed group most of them together in a chapter devoted primarily to Jews, showing an attempt to lay the groundwork for specific restrictions concerning Jews. If anything, it is the theologians, such as Augustine, who are responding to social and legal realities and not the other way around: confronted with Emperors who issued legal guarantees to Jews, they found theological justifications for a social status quo that they had not chosen, that explained why Christians allowed Jews to live in their midst. ${ }^{6}$

In Muslim societies, Qur'än and Hadith define the status of the dhimmi, protected minorities (principally Jews and Christians). This status on the whole accorded them protection from the violence and expulsions that often faced Jews and Muslims in late medieval Europe. Hundreds of legal texts from Muslim Spain, Sicily and elsewhere testify to the role of religious minorities and to the legal questions posed by their daily relations with the Muslim

\footnotetext{
Linder, The Legal Status of the Jews in the Roman Empire, 157.

Augustine, De civitate Dei, XVIII : 46.

Juster, Les Juifs dans l'Empire romain.

Nemo-Pekelman, Rome et ses citoyens Juifs.

I have developed this argument in greater detail in Tolan, Lex alterius.
} 
majorities. Fatwās (judicial consultations) and hisba manuals (regulations concerning marketplaces and urban space) deal with everything from the reliability of Jewish and Christian witnesses in court trials to dress restrictions. Some of these texts also deal with the situation of Muslims who found themselves in the position of minorities among Christians, whether temporarily (on Italian ships, for example) or permanently (under the dominion of Christian kings of Sicily or Spain).

While Jews were everywhere the minority, their relations with the adherents of other religions were also based on sacred texts (the Torah) and on the legal opinions of the Talmud. Various Jewish authors of Medieval Europe, from Cordova to Krakow, in texts such as biblical commentaries, letters, or responsa, offered legal advice to fellow Jews on the proper and legal limits to relations with Christians and Muslims.

There is thus a rich and varied corpus of texts dealing with the legal status of religious minorities in pre-modern Europe. These texts, in Latin, Arabic, Greek, Hebrew and Aramaic (and also in Medieval Spanish, Portuguese, and other European vernaculars), are dispersed in libraries and archives across Europe.

The ERC project RELMIN (www.relmin.eu) has created a database containing many of these texts. The database (http://www.cn-telma.fr/relmin) contains texts in the original languages (principally Latin, Arabic, Greek and Hebrew, but also in the European vernacular languages). The database is consultable in English and in French: each text is translated and a brief commentary, explaining its historical significance, is included, as are references to the relevant bibliography. These sources are fully searchable, in the various languages used. The use of thematic keywords will allow comparative searches of texts from different religious traditions (e.g., ablutions or dietary restrictions). The website also allows access to the various seminars and conferences organized by the project (text, audio and video), to the proceedings of the conferences, and to other articles posted by members of the RELMIN research team. This database provides a unique and valuable tool for researchers in the history of minority law and in the history of interreligious relations. It serves as an eloquent testimony to the permanence and ubiquity of interreligious cohabitation in Europe.

Interdisciplinary and cross-cultural research on the status of minorities in pre-modern Europe RELMIN's team and collaborators have embarked on the comparative study of these sources and have explored their implications for research in the history of interreligious relations. The database was put together by a team including myself, 4 doctoral students, 13 post-docs and a number of invited guest scholars. The team of researchers assembled in Nantes is interdisciplinary (including scholars in law, religion, history, Greek, Latin, and Arabic) and international (with members from France, Spain, the UK, Israel, Algeria, Italy, Poland, Turkey, Canada, and the USA).

In March 2011, I organized with Maribel Fierro a conference at the Centro Superior de Investigaciones Científicas (CSIC) in Madrid a conference on The Legal Status of Dimmi-s in the Islamic West; we subsequently published the acts of this conference as the first volume in our collection Religion and Law in Medieval Christian and Muslim Societies with Brepols publishers. ${ }^{7}$ There had been no previous volume devoted to the legal status of dhimmis in al-Andalus and the Maghreb. This is all the more surprising since the treatment of dhimmis, in Muslim Spain and in the rest of the classical dàr al-islam, has provoked interest and con-

7 Fierro and Tolan, The Legal Status of dimmi-s. 
troversy since the nineteenth century. Indeed, for some nineteenth-century scholars of Wissenschaft des Judentums (Jewish studies), Muslim Spain evoked a golden age, when Jews benefited from tolerance and as a result contributed fully to the rich intellectual and cultural life of Andalusian society. These scholars contrasted the situation in al-Andalus with that of Christian Europe, which they often saw as a vale of tears punctuated by persecution and expulsion. In Peninsular historiography, debate about the »tolerant« or »intolerant« nature of medieval Muslim and Christian societies has often masked controversy about the roots of problems of contemporary Spain: praising Muslim tolerance and heaping the blame for Spain's problems onto the Catholic Inquisition was a good way to attack the modern Spanish Catholic church and the conservative regimes closely aligned with it.

But more fundamentally, our work was useful in showing the diversity and complexity of dhimmi communities and their relationships with Muslim rulers. The articles collected here call into question the textbook images of a dhimmi system, supposedly based on the Pact of 'Umar, traditionally dated to the reign of 'Umar I (634-644), which some historians date to that of 'Umar II (717-20), in fact a document whose most extensive written versions date from the twelfth century. ${ }^{8}$ This text purports to be a letter from the Christian community of an unnamed Syrian city to the Caliph 'Umar. The Christians submit themselves to the Caliph's rule and promise not to proselytize, to build new churches or monasteries, to hold religious ceremonies in public, or to display crosses outside their churches. They are not to prevent anyone from converting to Islam. They are not to imitate the dress of Muslims, but to wear specific and recognizable clothing, in particular the zunnār, a distinctive belt. They also commit themselves to providing hospitality for traveling Muslims, to offer them their seats, and to show them deference. According to the traditional narrative, this dhimma system, elaborated by the Umayyads in eighth-century Syria, was systematically applied to Christian and Jewish communities in the lands conquered by Muslims (and subsequently to other communities to which dhimmi status was accorded). A key aspect of the system (curiously omitted from the Pact of 'Umar) is specific taxation: above all the jizya (capitulation tax), but also the kharāj (tax on land held by non-Muslims). Antoine Fattal's groundbreaking monograph on the dhimmi system, published in Lebanon in 1958, has remained the standard treatment of the question for over fifty years. ${ }^{9}$

Yet in fact when one looks closely at the early legal texts or chronicles from both the Mashreq and the Maghreb, there is little evidence for a standard, uniform dhimmi system, but rather a wide variety of local adaptations. Even for the jizya, often presented as the linchpin of this system, there is no standard model. For Alfonso Carmona, the classic jizya model (to the extent one ever existed) was in fact a product of the Abbasids: he shows how in the period of the Islamic conquest of Spain, fiscal policy towards conquered Christians was quite varied and often based on practical considerations and respect for local traditions. The "jizya" could at times be imposed on individuals but also on groups; sometimes it was levied on lands (blurring the distinction between jizya and kharāj). ${ }^{10}$ As Annliese Nef shows, the jizya was not systematically levied either in seventh-century Egypt or in ninth-century Sicily. ${ }^{11}$

8 Oulddali, Ahmed, Notice $\mathrm{n}^{\circ} 1068$, projet RELMIN, Le statut légal des minorités religieuses dans l'espace euroméditerranéen (Ve- XVe siècle), edition électronique Telma, IRHT, Institut de Recherche et d'Histoire des Textes - Orléans. Retrieved on 16 May 2015: http://www.cn-telma.fr/relmin/extrait1068/.

9 Fattal, Le statut légal des non-musulmans.

10 Carmona, Doctrina sobre la ğizya en el Occidente islámico pre-moderno.

11 Nef, Le statut des dimmī-s dans la Sicile aghlabide. 
Marina Rustow mentions cases of exemptions from jizya accorded to individual dhimmis in Mamluk Egypt. ${ }^{12}$ Fifteenth-century Tlemcen muftì Qāsim al-'Uqbānī was asked whether the jizya is to be imposed on all Jews or only those who live in the cities; as one might expect, he affirmed the principle that it applied to all male Jews who lived as dhimmis under the protection of Muslim rulers: but the very fact that the question was raised, as Elise Voguet suggests, indicates that rural Jews were often in practice exempted from paying. ${ }^{13}$

The same wide variance in practice could be shown in other purported stipulations of the dhimmī system. Fifteenth-century Tlemcen muftì Sīdī Muhammad al-'Uqbānī affirms that local Jews ride horses and wear turbans, just like Muslims (as Elise Voguet shows). Or take the example of church bells: one frequently reads that Christians were prohibited or discouraged from bell-ringing. In fact, here too, practice varied widely, as I have shown elsewhere. ${ }^{14} \mathrm{Ibn}$ 'Abd al-Barr's eleventh-century manual al-Käfī fì figh ahl al-madīna, analyzed by Christian Müller, which details restrictions on dhimmis, says nothing about restrictions on bell-ringing; nor are dhimmis prohibited from riding horses (although they may not own them). ${ }^{15}$

The sixth to eleventh centuries are a crucial formative period for Jewish communities in Byzantium and Latin Europe: this is also a period for which sources are scarce and about which historians have often had to speculate on the basis of scant evidence. Just as there had been no volume on the status of dhimmis in the Islamic west, there seemed a need for a fresh synthesis on the legal status of Jews in this key period. For this reason I organized with Nicholas de Lange, Capucine Nemo-Pekelman and Laurence Foschia a conference in the Royal Abbey of Fontevraud in October 2011 on "Jews in Early Christian Law: Byzantium and the Latin West, 6th-11th centuries " (published as volume 2 in the RELMIN series). ${ }^{16}$ The legal sources studied in this volume provide a relative wealth of textual material concerning Jews, and for certain areas and periods are the principal sources. While this makes them particularly valuable, it also makes their interpretation difficult, given the lack of corroborative sources. When the council of Vannes in 465 prohibits Christian clerics from sharing meals with Jews, does this mean that there were Jews in Brittany and that clerics had been eating with them? Or does this prohibition reflect debates among the bishops present, motivated by theological concerns rather than practical issues? ${ }^{17}$ The lack of context (and notably of any evidence of Jewish presence in Brittany before 1209), makes the latter answer more probable, but still uncertain.

Indeed, some historians have doubted the very existence of Jewish communities north of the Alps and the Pyrenees before the eleventh century. ${ }^{18}$ Could the Jew of some of the legal texts be a straw man, a "hermeneutical Jew « like that of many Christian anti-Jewish polemical works? While the Jew with whom one should not eat (according to Church councils such as

15 Müller, Non-Muslims as Part of Islamic law.

16 Tolan et al., Jews in Early Christian Law.

17 Nemo-Pekelman, Capucine, Notice n40867, projet RELMIN, Le statut légal des minorités religieuses dans l'espace euro-méditerranéen (Ve- XVe siècle), edition électronique Telma, IRHT, Institut de Recherche et d'Histoire des Textes - Orléans. Retrieved on 16 May 2015: http://www.cn-telma.fr/relmin/extrait40867.

18 This was the view put forward by Michael Toch in his unpublished oral contribution to the Fontevraud conference, based on arguments developed in the final chapter of Toch, The Economic History of European Jews. See also Toch, The Jews in Europe. 
that of Vannes) may well correspond to theological concerns (and hence to "hermeneutical « Jews), some stipulations in the Carolingian legislation discussed by Philippe Depreux clearly do not: when various ninth- and tenth-century legal texts use formulas such as "Iudei et ceteri mercatores" ("Jews and other merchants"), they clearly mean not Old Testament Jews, but real individuals present in Carolingian towns - indeed, the formulation shows that the Jew is seen as the merchant par excellence. ${ }^{19}$ Yet Jewish settlement in the Empire was uneven: principally in Italy and southern Gaul (including Lyon), with only occasional evidence of the presence of Jews, principally travelling merchants, in the northern and eastern parts of the Empire. It is only in the eleventh century that Jews begin to settle north of the Alps in any significant numbers, in particular in the towns of the Rhine valley, with the encouragement of local authorities, lay and ecclesiastical.

It is also impossible to know, in the great majority of cases, to what extent these laws were enforced and obeyed. What are we to make of the fact that certain measures are repeated frequently? For Ralph Mathisen, the prohibitions of intermarriage and of Jewish office-holding, in fifth and sixth-century imperial legislation, were ineffectual: the repetition of these measures is a sign of the impotence of the emperors to enforce the laws, rather than an indication of real Jewish social and legal inferiority. The severe anti-Jewish laws proclaimed by Visigothic councils and kings were sporadically enforced at best. ${ }^{20}$ Yet for Bat-Sheva Albert, the repetition of certain measures (including those concerning Jews) could above all indicate a king's (or a council's) need to reaffirm certain legal principles, and does not necessarily indicate whether or not the laws were respected. ${ }^{21}$ Thus repeated laws against Jews owning Christian slaves may say more about the zeal of the Christian legislators than about social realities. As Rachel Stocking shows, when the third council of Seville (c. 624) reacts to accusations that forced converts are presenting their Christian neighbors' children for baptism to avoid baptizing their own children, we cannot know the truth behind these allegations - but it is clear that the bishops take advantage of the accusation to affirm their authority. ${ }^{22}$

Yet in other cases we have clear evidence that many laws were not observed - even by the kings that proclaimed them. In Visigothic Spain, councils and kings regularly ruled that Jews could not be placed in positions of authority over Christians; yet King Erwig (680687), in reiterating these prohibitions, allows an exception if such employment is in the public interest - a rather large loophole. In other cases we have exemptions or privileges granted to specific Jews, individuals or communities: The imperial letters of protection for individual Jews, granted by Louis the Pious' court around 825, which for Johannes Heil were a reaction to attempts to challenge the Jews' economic situation by baptizing and thereby removing their servants from their households. ${ }^{23}$ Indeed, if these Jews took the trouble to seek out these privileges and the emperors to grant them, they must have responded to real needs. We know that in the Middle Ages the power of justice was a source of income, both through fines and through granting (or selling) of exemptions or privileges: that certainly seems to be the case here.

19 Depreux, Les juifs dans le droit carolingien.

20 Mathisen, The Citizenship and Legal Status of Jews in Roman Law.

21 Bat-Sheva, Les communautés juives.

22 Stocking, Forced Converts, »Crypto-Judaism«, and Children.

23 Heil, Getting them in or Keeping them out? 
The cities and towns of Europe and the Mediterranean World constituted a crucial space to study interreligious relations in the Middle Ages: both because it was above all in cities that members of different faiths lived cheek by jowl and had to work out how to compromise between the requirements of their religious law and the realities of day-to-day interaction, and because the sources which we have at our disposition give a large place to the cities, and in particular to the urban elites of the different religious communities. For these reasons Stéphane Boissellier and I thought it worthwhile to organize a conference on "Religious cohabitation in European towns (10th-15th centuries) « at the Fondation des Treilles in Tourtour, Provence (published as volume 3 of our Brepols collection). ${ }^{24}$

We dealt principally, though not exclusively, with legal sources: imperial and royal laws, urban charters and statutes, canon law, legal commentaries, learned legal opinions (in the form of fatwās or responsa), etc. The presupposition was that these sources, underused by social and urban historians, could yield precious evidence of day to day contact between members of different religious communities living in the same city. The subjects ranged from the twelfth century to the fifteenth and from Portugal to Hungary, Crete and the Mamluk sultanate. Yet the cities of this broad region faced similar problems and challenges, and their legal scholars (in general members of the religious elite) worked under similar constraints and with similar methods and textual sources. Hence it is indeed possible to draw at least tentative conclusions on several key issues. First of all, legal texts can provide indications of the range and types of interreligious contact, and of the tensions or legal problems such contact could cause. Secondly, and somewhat paradoxically, such contact is attested principally in the texts of laws that attempt to limit or control it. In the absence of corroborating evidence, we may wonder to what extent such laws were effective in limiting and controlling contact, and indeed to what extent they reflect real social concerns of an urban elite, rather than abstract intellectual exercises by a clerical clique.

These cities are politically very different: some dominated by princes who rule over a large territory, some run by an oligarchy of prominent citizens. They all have complex and stratified social hierarchies: our focus on the role of religious minorities must not blind us to the fact that religious difference is merely one distinguishing factor (albeit an important one) among many: wealth, birth, language, profession, etc. Often these hierarchies are inscribed in the very monuments and layout of the city: in the case of "colonial "Venetian Candia (Heraklion), as Aleida Paudice shows, Venetian Catholic monuments dominate the city-scape, with distinct (and subordinated) spaces for Greek Christian and Jewish communities. ${ }^{25}$ Space is conditioned to reflect these hierarchies, as is time: Elisheva Baumgarten shows, through the example of medieval Hebrew texts dealing with issues of calendars and chronology, that Ashkenazi Jews were familiar with the rhythms of the Christian calendar, the various feast days of the saints, etc. ${ }^{26}$ Jews of Crete or Ashkenaz recognized the spatial and temporal symbols of their own subordination to Christian rule, which did not of course prevent them from providing subversive readings of the dominant discourse (for example, by denigrating the saints to whom churches were built and whose feast days were celebrated).

We have seen that the sources that tell us most about interreligious social relations are often legal texts that attempt to regulate them: how can we know to what extent (if any) these attempts were successful? Tahar Mansouri demonstrates how commonly Málikì 'ulamá' in

24 Tolan and Boissellier, Religious Cohabitation in European Towns.

25 Paudice, Religious Identity and Space in Venetian Candia.

26 Baumgarten, Christian Time in a Jewish Miscellany. 
the Maghreb criticized Muslim rulers for favoring Jews and Christians, in disrespect of the proper hierarchy between Muslims and dhimmis. ${ }^{27}$ Pierre Moukarzel paints a similar picture in the Mamluk sultanate: men of religion objected to the privileges shown to European merchants: allowing them to eschew sumptuary laws and ride horses, permitting them to be judged by the sultan's court and not the qădìi, etc. ${ }^{28}$ Were these merchants to be considered dhimmis? Foreigners protected by an amann? Hence one of the frequent themes of many of these legal sources, from fatwās and responsa to papal bulls, is that the proper hierarchies between faithful and infidel are not being respected.

Indeed, many jurists and scholars seem to rail to little effect against firmly entrenched social practices. Two Māliki fatwās, one from the twelfth century and one from the fifteenth, discourage Muslim traders from venturing to the dar al-harb, as Dominique Valérian demonstrates, but this did not prevent Muslim merchants from traveling to European ports. ${ }^{29}$ Katalin Szende notes that some Hungarian royal laws concerning Jews represent an attempt to respond to papal and episcopal pressures more than they reflect any real royal will to regulate or restrict Christian-Jewish interaction. ${ }^{30}$ It is moreover often difficult to know when these texts reflect lived social reality and when they merely are intellectual exercises concerning hypothetical cases. When (in Farid Bouchiba's article) Ibn Rushd discusses the slaughter of an animal jointly owned by a Muslim and a dhimmi, we seem to be in the presence of an interesting example of economic partnership. ${ }^{31}$ Yet when the same author discusses whether or not Muslims can eat grasshoppers that have been killed by Mazdeans, we realize we are in an intellectual exercise based on the commentary of authoritative Eastern texts, far from any social realities of Andalusian cities.

Various European polities expelled their Jewish or Muslim subjects between the twelfth and seventeenth centuries. The expulsions were recorded and commemorated by Jews and Muslims in exile, for whom the experience of expulsion and exile became a touchstone for the construction of community identities in their new homes. With a group of scholars from Budapest and Heidelberg working on the dynamics of diasporas we organized a conference at the Central European University in Budapest in June 2013 on Expulsion and Diaspora Formation: Religious and Ethnic Identities in Flux from Antiquity to the Seventeenth Century. ${ }^{32}$ The questions we addressed were: How does the experience of expulsion create, deconstruct, or transform group identities? To what extent do diasporas create cultural identities bridging large spans of time and space? How do the far-flung elements of those diasporas see their links to each other and to the (real or mythicized) land of origin?

A wave of expulsions of Jews in the twelfth and thirteenth centuries amounts to what one could call a first age of expulsion. In 1182, Philippe II expelled the Jews from the French Royal domain. In the following decades, Jews were expelled from Brittany (1240), Gascony (1287), Anjou (1289), England (1290), and France (1306): not to mention many more local expulsions, notably from English and French towns. ${ }^{33}$ Some of these expulsions were short-

27 Mansouri, Les dhimmis dans les documents de chancellerie.

28 Moukarzel, La législation des autorités religieuses et politiques.

29 Valérian, La présence des musulmans étrangers dans les ports chrétiens.

30 Szende, Laws, Loans, Literates.

31 Bouchiba, Cohabitation religieuse et pratiques alimentaires.

32 Tolan, Expulsion and Diaspora Formation.

33 For a comparative study of the expulsions of 1290, 1306 and 1492, see Kriegel, Mobilisation politique et modernisation organique. 
lived, others long-lasting; the causes and consequences of each are different. Yet each would confirm the stereotype of the Jew as essentially rootless, a foreigner who, since he or she is not part of the community, can be expelled from it. While each of these events is different, they occur against a common background of economic and social upheaval and of growing violence against Jews. From the late fifteenth century, fresh expulsions compelled Jews to leave Spain (1492), Portugal (1497), Provence (1501), and various Italian and German towns. Muslims were expelled from Sicily in 1224 and settled in the southern Italian town of Lucera; in 1300, King Charles I sold into slavery the Lucera Muslims who refused to accept baptism. Muslims were expelled from the various Iberian kingdoms over the course of the sixteenth century and in 1609 the Moriscos (nominally Christian descendants of Spanish Muslims) were in turn expelled.

The expelled arrive in a new host society, which often welcomes them with some ambivalence, if not with suspicion or hostility. How do the new involuntary immigrants integrate their new homelands? This of course depends on a wide variety of factors: language, diet, religion, etc. And of course small numbers integrate more readily than large groups, which are more likely to cling to a specific group identity within the larger society. An important element is the attitude of the authorities of the new lands of exile. A Diaspora community, in theory, conserves its distinct identity (linguistic, cultural, religious, etc.) within a foreign host society. But in fact, of course, the degrees of assimilation and acculturation vary widely, and over time certain diaspora communities blend into the host societies completely. Others keep a distinctive identity while adopting important elements of their host cultures: within the Medieval Jewish diaspora, Iraqi Jews and English Jews resemble in many ways more their respective host cultures than they do each other. Indeed the Medieval Jewish experience is a prime example of what some scholars have referred to as a diaspora within a diaspora. After 1492 the notion of galut (exile), which traditionally referred to Jews' exile from Israel, came to refer to their new exile from the Iberian Peninsula, referred to as galut sefarad. In other words, it seems that common sentiment of a diaspora culture in exile grew up through difficult adjustments to new host communities. The extent to which the Sefarad immigrants succeeded in imposing their own distinct culture is testified by the "Sefardization " of many other Mediterranean Jewish communities of the Ottoman Empire and North Africa.

Iberian Muslims, like their Jewish counterparts, formed a new diaspora community in areas where their numbers were significant (in parts of North Africa in particular). For Jewish and Muslim descendants of these exiles (or for those who identified themselves as such), the narratives of expulsion and persecution became founding myths of a communal or diasporic identity. They also became stock figures of European literature: the rootless Morisco is already a striking figure in Cervantes; he will be rediscovered by European and American romantics of the nineteenth century, whose travels to Andalusia become the occasion for musings on a lost world of beauty and chivalry. Expulsion and its memory live on in narratives that often seek to simplify or deny all the hybridity and ambiguity of the diaspora or exile status: caught between isolation and assimilation, between breaking with the past and dreaming of its renewal.

2013 would have marked the 10oth birthday of Bernhard Blumenkranz. Born in Vienna, Blumenkranz fled the Anschluß and settled in Switzerland and (after the war) France, where he initiated a series of groundbreaking studies on the history of medieval Jewish-Christian relations. The anniversary was the occasion for us to reflect on the legacy of Blumenkranz, his lasting impact on work in the field and the directions the field has moved since his death in 1989. With Vienna-based colleagues Martha Keil and Philippe Buc, we organized a conference there bringing together prominent scholars in the field from France, Austria, other 
European countries, North America and Israel: the proceedings have been published as volume 6 of our series. ${ }^{34}$ The volume brings together 16 essays representing new research in fields in which Blumenkranz was a pioneer: the relationship between the Medieval Church and Jewish communities, the question of proselytization and conversion of Jews, the cartography of Jewish communities, and the representation of Jews in Christian art.

Throughout the RELMIN project, we have faced the problem of the functions of law: to what extent did laws concerning religious minorities reflect real social practice and to what extent were they reflections of abstract religious and legal principles? We addressed these issues in a conference organized at the Casa Arabe in Córdoba in April 2014 entitled »Law and Religious Minorities in Medieval Societies: between Theory and Praxis " (publication in 2015 as volume 7 of the RELMIN series). We examined a number of cases in which jurists engaged in the building or maintenance of barriers between majority and minority communities: prohibitions or restrictions of Christian participation in Muslim funerals, festivals, etc. (as Herman Teule shows); restrictions on marriage; restrictions on "infidels« bathing with the faithful in public baths (Marisa Bueno). Language use could also help minority communities express and consolidate legal traditions and institutions: as David Wasserstein shows, Jewish communities in the Muslim world had more success doing this (through the use of Hebrew \& Aramaic) than did Christian communities (who tended to adopt Arabic as a liturgical language).

While such legal documents show a will to separate and distinguish along religious divides, others show attempts to incorporate members of other faith groups into legal systems. For Mark Cohen, dhimmi legal systems in twelfth-century Egypt are an integral part of overarching Muslim legal system; one could almost say that Maimonides serves as a Jewish mufti. While shari'a in theory prohibited dhimmis from appearing as accusers or witnesses in Muslim courts, various Maliki jurists strive to find appropriate and specific ways for dhimmis to swear oaths and more generally to participate in the legal system (Camilla Adang; Delfina Serrano). And Ana Echevarria examines the parallel integration of mudejar legal system into Castilian legal system. Moreover, the legal institutions and practices of the dominant culture often have a profound impact on the minority legal systems: Herman Teule gave examples of how Syrian Christian law is influenced by Muslim law, while Johannes Pahlitzsch examines the adoption and adaptation of the waqf system into Melkite law.

Our final conference, in October 2014, brought together 38 colleagues from all over the world for a series of lectures and round-table debates in which we drew conclusions from our five years of collective work in a number of thematic areas: the constitution of authoritative corpus of law in Medieval Jewish, Christian and Muslim societies; understanding the role of religious difference in the establishment of a specific legal status; the use of social criteria to distinguish and separate religious communities; and the question of access to justice by members of religious minorities. The conference acts will be published in 2016.

In addition to the proceedings of the conferences, we are publishing dissertations of the $\mathrm{PhD}$ students and post-docs who have worked with RELMIN. Clara Maillard's book, Les papes et le Maghreb aux XIIIème et XIVème siècles (RELMIN 4, published in 2014), analyzes over 200 papal letters concerning North Africa. These letters, addressed to Muslim rulers (in particular to Almohad Caliphs), to bishops of Marrakech, to friars resident in North Africa, or to a variety of Christian rulers, are an important source for the history of Christian

34 Buc et al., Jews and Christians in Medieval Europe. 
mission to Maghreb and Christian communities there. Her conclusion is that the papacy was guided throughout this period by a flexible pragmatism in its dealings with the Maghreb; this should prove a useful corrective to interpretations of medieval Christian-Muslim relations that exaggerate the role ideology plays in shaping events, even as it illuminates the real limits of the power of later medieval popes.

Youna Masset's La procédure judiciaire et les minorités religieuses dans la couronne d'Aragon aux XIIème-XIème siècles (to be published in 2016) examines the place of Muslims and especially Jews in the court system of the crown of Aragon. While in theory Jews and Muslims had judicial autonomy for internal community affairs, in practice this was often compromised both from above (as royal justice expanded at the expense of lower jurisdictions) and from below (as Jews or Muslims unsatisfied with the judgment rendered by Jewish or Muslim judges could and often did appeal to municipal or royal judges).

Finally, two theses examine in detail the place given to dhimmis in two important Mălikì texts from the twelfth and thirteenth centuries. Farid Bouchiba (Le statut légal des dhimmi-s en al-Andalus selon les auteurs malikites, VII-X siècles : Étude de la condition juridique du juif et chrétien en terre d'Islam; to be published in 2016) focuses on the al-Bayān wa l-tahsill wa l-shar wa l-tawjīh wa l-ta'lìl fì masā'il al-Mustakhraja, magnum opus of one of the most important jurists of Islamic Spain, Ibn Rushd al-Jadd (d. 1126), qāḍi of Cairo (and grandfather of the philosopher Averroes). Geraldine Jenvrin (Élaboration du statut légal du dhimmì dans la doctrine malikite andalouse (XIe-XIIIe): Exégèses coraniques et sciences juridiques; to be published in 2017) examines the same issues of the place of dhimmis in Islamic society through the perspective of one of the middle ages' principal Qur'ann commentaries, written by Cordoban scholar al-Qurțubì (d. 1276).

What, then, can be gained from the comparative approach we have taken in RELMIN? Let us look at a few examples, of how these legal texts deal with key issues in interconfessional relations: food and the sharing of meals, sexual relations and clothing restrictions, delimitation of sacred or cultic space, and access to justice. Each of these subjects has been the object of discussion and debate over the five years of the project and the comparative approach has proved fruitful in each case.

Over sixty of the texts in the RELMIN database deal with food in one way or another: which foods one can eat or cannot eat, the possibility (or not) of "contamination " of food or drink through contact with an infidel, the legality (or not) of buying food from an infidel or sharing a meal with him. We have seen that the council of Vannes in 465 prohibits Christian clerics from sharing meals with Jews. Food prohibitions - what one can eat, and above all with whom one can eat - have often been used to mark and separate the faithful from outsiders. ${ }^{35}$ Rena Lauer shows how Jewish authorities in Crete worried about the effects of Jews using gentile bake-houses; Farid Bouchiba gives examples of how Mālikì jurists tried carefully to determine which meat was licit, depending on who killed the animal in what circumstances. ${ }^{36}$ Ashkenazi Jews often sold cuts of meat that they considered non-kosher (notably the hind quarters) to Christians: either directly to consumers or to Christian butchers. This provokes the ire of various ecclesiastical authorities. The synod of Esztergom in Hungary in the early twelfth century prohibited Christians from buying meat that had been

35 Freidenreich, Foreigners and their Food.

36 Rena Lauer, Jewish Women in Venetian Candia; Bouchiba, Cohabitation religieuse et pratiques alimentaires. 
»spurned« by Jews. ${ }^{37}$ We find similar prohibitions reiterated by popes such as Innocent III in 1208 and in civil legislation, notably in Catalonia in the fourteenth and fifteenth centuries. ${ }^{38}$ We also find Jewish authorities, such as Solomon Ibn Adret of Catalonia, addressing the question of whether meat touched by a gentile butcher is permissible to Jews. ${ }^{39}$ While the consumption of meat prepared by dhimmi butchers was in theory legal according to Muslim law, it provoked the unease of some Mālikī jurists such as Abū Zayd al-Qayrawānī who discouraged it. ${ }^{40}$

Wine is of course illegal for Muslims but permitted for dhimmīs: Adday Hernández López gives an in-depth exploration of the problems posed by the sale of wine, legitimate when between dhimmis but illegal if a Muslim is involved. ${ }^{41}$ Christian and Jewish writers addressed the question of whether wine could be corrupted through contact with infidels, rendering it unfit for consumption or for use in the Eucharist. ${ }^{42}$ Eating and drinking with infidels posed problems in part because it could lead to other kinds of intimacy. A 1267 synod of the Polish Church ruled:

"We prohibit all Christians of this province under the penalty of excommunication (the following): they should not accept that a Jew or a Jewess to cohabit with them, nor should they dare to eat and drink with them, or dance and hop merrily with them during their weddings or feasts. Christians should not buy meat and other food from Jews, so that Jews, who regard them as enemies, could not fraudulently poison Christians. ${ }^{43}$ «

37 Mazur, Jery, Notice $\mathrm{n}^{\circ} 254225$, projet RELMIN, Le statut légal des minorités religieuses dans l'espace euro-méditerranéen (Ve-XVe siècle), edition électronique Telma, IRHT, Institut de Recherche et d'Histoire des Textes - Orléans. Retrieved on 15 May 2015: http://www.cn-telma.fr/relmin/extrait254225/.

38 Tolan, John, Notice $\mathrm{n}^{\circ}$ 30493, projet RELMIN, Le statut légal des minorités religieuses dans l'espace euroméditerranéen (Ve-XVe siècle), edition électronique Telma, IRHT, Institut de Recherche et d'Histoire des Textes Orléans. Retrieved on 15 May 2015: http://www.cn-telma.fr/relmin/extrait30493/; Muntane Santiveri, Josep Xavier, Notice $\mathrm{n}^{\circ}$ 252412, projet RELMIN, Le statut légal des minorités religieuses dans l'espace euro-méditerranéen (Ve-XVe siècle), edition électronique Telma, IRHT, Institut de Recherche et d'Histoire des Textes - Orléans. Retrieved on 15 May 2015: http://www.cn-telma.fr/relmin/extrait252412/; Muntane Santiveri, Josep Xavier, Notice $\mathrm{n}^{\circ}$ 252389, projet RELMIN, Le statut légal des minorités religieuses dans l'espace euro-méditerranéen (Ve-XVe siècle), edition électronique Telma, IRHT, Institut de Recherche et d'Histoire des Textes - Orléans. Retrieved on 15 May 2015: http://www.cn-telma.fr/relmin/extrait252389/.

39 Koryakina, Nadezda, Notice $\mathrm{n}^{\circ} \mathbf{2 5 2 2 5 5}$, projet RELMIN, Le statut légal des minorités religieuses dans l'espace euro-méditerranéen (Ve-XVe siècle), edition électronique Telma, IRHT, Institut de Recherche et d'Histoire des Textes - Orléans. Retrieved on 15 May 2015: http://www.cn-telma.fr/relmin/extrait252255/.

40 Çelebi, Emre, Abī Notice ${ }^{\circ}$ 252580, projet RELMIN, Le statut légal des minorités religieuses dans l'espace euro-méditerranéen (Ve-XVe siècle), edition électronique Telma, IRHT, Institut de Recherche et d'Histoire des Textes - Orléans. Retrieved on 15 May 2015: http://www.cn-telma.fr/relmin/extrait252580/.

41 Hernández López, La compraventa de vino entre musulmanes y cristianos dimmíes.

42 See e.g. Freidenreich, David, Notice ${ }^{\circ}{ }^{2} 24091$, projet RELMIN, Le statut légal des minorités religieuses dans l'espace euro-méditerranéen (Ve-XVe siècle), edition électronique Telma, IRHT, Institut de Recherche et d'Histoire des Textes - Orléans. Retrieved on 15 May 2015: http://www.cn-telma.fr/relmin/extrait244091/; Koryakina, Nadezda, Notice $n^{\circ} 244130$, projet RELMIN, Le statut légal des minorités religieuses dans l'espace euro-méditerranéen (Ve-XVe siècle), edition électronique Telma, IRHT, Institut de Recherche et d'Histoire des Textes - Orléans. Retrieved on 15 May 2015: http://www.cn-telma.fr/relmin/extrait244130/; Tolan, John, Notice $\mathrm{n}^{\circ} 30493$, projet RELMIN, Le statut légal des minorités religieuses dans l'espace euro-méditerranéen (Ve-XVe siècle), edition électronique Telma, IRHT, Institut de Recherche et d'Histoire des Textes - Orléans. Retrieved on 15 May 2015: http:// www.cn-telma.fr/relmin/extrait30493/.

43 Mazur, Jerzy, Notice ${ }^{\circ}$ 252878, projet RELMIN, Le statut légal des minorités religieuses dans l'espace euro-méditerranéen (Ve-XVe siècle), edition électronique Telma, IRHT, Institut de Recherche et d'Histoire des Textes - Orléans. Retrieved on 15 May 2015: http://www.cn-telma.fr/relmin/extrait252878/. 
The synod posits a fundamental enmity between Jews and Christians: the pretext for prohibiting purchase of food from Jews is that they might try to poison Christians. Yet the rest of the text belies this: the real worry seems to be intimacy between Jews and Christians who eat, drink, dance and party together and who share the same lodgings.

Indeed, the prohibitions of eating and drinking together are often linked with concerns about sexual intimacy. Bathhouses, too, could provide opportunities for illicit interreligious sexual encounter: in Muslim Spain, regulations separated men from women (either assigning to them different hammäms or different days of the week). The Christians kingdoms tended to segregate not only sexually but according to religion, as Olivia Remie Constable notes, assigning specific days to Jews and Muslims. The usually implicit and occasionally explicit concern is that interreligious frequentation of bath houses could cause unwanted proximity and in some cases sexual intimacy. ${ }^{44}$

It was illegal for Christians to marry non-Christians: Roman Christian emperor Theodosius I in 388 prohibited marriage between Christians and Jews, a prohibition promulgated in the Theodosian Code (in 438) and reiterated by the church councils of Orléans 2 (533), Clermont 1 (535) and Orléans 3 (538), from which it was incorporated into Gratian's Decretum. ${ }^{45}$ Various popes and church councils sought to enforce separation of Christians from non-Christians to avoid opportunities for sexual relations: we see this concern for example in various bulls of Innocent III (1198-1216); under Innocent's direction, the Lateran IV council requires Jews and Muslims to dress differently than Christians so that they might be recognized and that sexual contact with them be shunned. ${ }^{46}$ Brian Catlos gives examples of how Aragonese officials sought out and punished Muslim women who had been sexually intimate with Christian men. ${ }^{47}$ Preventing interfaith sexual encounters is still an issue in late fifteenth-century Portugal, as François Soyer shows. ${ }^{48}$

Another important issue that has been the object of research and discussion over the last five years is the nature of sacred space. Jurists attempted both to delimit and protect sacred precincts and to define the protection given to places of worship of minority religions. In the

44 Constable, From Hygiene to Heresy.

45 Nemo-Pekelman, Capucine, Notice ${ }^{\circ}{ }^{136982}$, projet RELMIN, Le statut légal des minorités religieuses dans l'espace euro-méditerranéen (Ve-XVe siècle), edition électronique Telma, IRHT, Institut de Recherche et d'Histoire des Textes - Orléans. Retrieved on 15 May 2015: http://www.cn-telma.fr/relmin/extrait136982/; Freidenreich, David, Notice ${ }^{\circ}$ 238307, projet RELMIN, Le statut légal des minorités religieuses dans l'espace euro-méditerranéen (VeXVe siècle), edition électronique Telma, IRHT, Institut de Recherche et d'Histoire des Textes ... Orléans. Retrieved on 16 May 2015: http://www.cn-telma.fr/relmin/extrait238307/; Freidenreich, David, Notice $\mathrm{n}^{\circ} 238304$, projet RELMIN, Le statut légal des minorités religieuses dans l'espace euro-méditerranéen (Ve-XVe siècle), edition électronique Telma, IRHT, Institut de Recherche et d'Histoire des Textes - Orléans. Retrieved on 16 May 2015 : http:// www.cn-telma.fr/relmin/extrait238304/; Freidenreich, David, Notice nº238305, projet RELMIN, Le statut légal des minorités religieuses dans l'espace euro-méditerranéen (Ve-XVe siècle), edition électronique Telma, IRHT, Institut de Recherche et d'Histoire des Textes - Orléans. Retrieved on 16 May 2015: http://www.cn-telma.fr/relmin/ extrait238305/; Sherwood, Jessie, Notice $n^{\circ}$ 40851, projet RELMIN, Le statut légal des minorités religieuses dans l'espace euro-méditerranéen (Ve-XVe siècle), edition électronique Telma, IRHT, Institut de Recherche et d'Histoire des Textes - Orléans. Retrieved on 16 May 2015: http://www.cn-telma.fr/relmin/extrait40851/.

46 Sherwood, Jessie, Notice $\mathrm{n}^{\circ} 30326$, projet RELMIN, Le statut légal des minorités religieuses dans l'espace euroméditerranéen (Ve-XVe siècle), edition électronique Telma, IRHT, Institut de Recherche et d'Histoire des Textes Orléans. Retrieved on 16 May 2015: http://www.cn-telma.fr/relmin/extrait30326/; Tolan, Of Milk and Blood. See also Fois, Physical Separation of Jews and Christians.

47 Catlos, Is It Country Air that Makes Infidels Free?

48 François Soyer, Prohibiting Sexual Relations. 
face of Christian violence against Jewish synagogues, various Christian Roman Emperors issued laws protecting Jews' rights to practice their cult and to maintain their synagogues. ${ }^{49}$ Māliki jurisprudence from the Middle Ages abounds with references to kanisas: churches and synagogues..$^{50}$ Various versions of the Pact of 'Umar affirm that Christians and Jews may not build new synagogues, but in fact this purported rule was enforced only sporadically. Alejandro García Sanjuán traces the doctrinal history of this question, showing how Mālikì jurists came to distinguish territories conquered by force (in which new kanisas could not be built), new cities founded by Muslims (where dhimmi sanctuaries were also prohibited), and territories which submitted to Islam by pact (sulh) (where new churches and synagogues could be built). ${ }^{51}$ Yet there is in fact little evidence that any ruler tried to enforce such distinctions: when we do have evidence of building restrictions or destructions, it is often attributable to more immediate social or political concerns: such is the case, for example, for the destructions ordered by Muhammad I in the 850s, at the height of the Cordoban martyrs' movement. Indeed, as Jean-Pierre Molénat suggests, the tripartite distinction may be an ex post facto justification of decisions made by ninth-century emirs, who permitted the construction of a number of churches and synagogues in the outlying districts of Cordoba. ${ }^{52}$ Most of the text mentioning of these churches and synagogues in the legal sources describe them as essential parts of the urban landscape. They can be used as appropriate places for Christians and Jews to take oaths, as Ahmed Oulddali notes. ${ }^{53}$ They also can be seen as places of danger, as Cyrille Aillet shows: some jurists, while not prohibiting Muslims from entering Christian churches, discourage it, since it could lead to contact with sacrilegious images or with impure substances such as blood or wine. Indeed various Arab poets had celebrated churches (and especially monasteries) as pleasure dens where adventurous souls could enjoy Bacchic excess. ${ }^{54}$

A constant concern of these legal scholars is the proper functioning of justice. Ahmed Oulddali has shown how in theory dhimmis were prohibited from bearing witness against Muslims, with a limited number of exceptions..$^{55} \mathrm{Ibn}$ 'Abd al-Barr addresses at length the question of dhimmis access to the judgment of a Muslim qādì, as Christian Müller demonstrates. ${ }^{56}$ While cases involving two Christians were in theory subject to the judgment of the bishop, they may in some cases be referred to the Muslim qādi, either at the behest of the bishop or at the request of the adjudicating parties. Why would two Christians (or Jews) prefer to submit their case to the $q \bar{a} d \bar{\imath}$ ? There could be a variety of reasons: perceived justice

49 See, for example, Nemo-Pekelman, Capucine, Notice ${ }^{\circ}$ 238489, projet RELMIN, Le statut légal des minorités religieuses dans l'espace euro-méditerranéen (Ve-XVe siècle), edition électronique Telma, IRHT, Institut de Recherche et d'Histoire des Textes - Orléans. Retrieved on 16 May 2015: http://www.cn-telma.fr/relmin/extrait238489/; Ne-

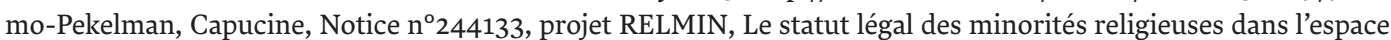
euro-méditerranéen (Ve-XVe siècle), edition électronique Telma, IRHT, Institut de Recherche et d'Histoire des Textes - Orléans. Retrieved on 16 May 2015: http://www.cn-telma.fr/relmin/extrait244133/.

50 Bouchiba, Eglises et synagogues en terre d'Islam.

51 Sanjuán, La formación de la doctrina legal.

52 Molénat, La fatwā sur la construction des églises.

53 Oulddali, Recevabilité du témoignage du dimmī.

54 Aillet, La construction des frontières interconfessionnelles.

55 Oulddali, Recevabilité du témoignage du dimmī.

56 Müller, Non-Muslims as Part of Islamic Law.

medieval worlds $•$ No. $1 \cdot 2015 \cdot 148-166$ 
or efficiency of the Muslim judicial system, higher expertise concerning the matter at hand (which could involve technical or commercial law), or simply a personal preference for the local qädì over a specific bishop or rabbi. ${ }^{57}$ It would be interesting to know what the Christian and Jewish judges who were being sidestepped thought of this: were they happy to defer to the qädì-s concerning issues in which they had little competence? Did they resent this circumventing of their authority? No doubt this phenomenon is to be understood in the broader context of competing jurisdictions and of "forum shopping ", a widespread phenomenon in both Muslim and Christian societies in the Middle Ages..$^{58}$

Indeed, the law court is an important place of contact (of conflict and conflict resolution), as Rena Lauer makes clear in her case studies of Jewish women in Candia law courts. ${ }^{59}$ Youna Masset shows that the Catalan town of Tortosa had distinct courts for Jewish, Muslim and Christian communities and in theory, in cases involving litigants from two different faith communities, each was to be judged by his or her own judge. ${ }^{60}$ Judith Olszowy-Schlanger's contribution to the Vienna conference shows how Jews not only could bring suits against Christians in English law courts; they could even present Hebrew documents as admitted evidence. ${ }^{61}$ Many of these documents are bilingual: in some of them, the Jewish contractor opposes a handwritten Hebrew formula attesting to his agreement to the Latin document. This suggests a certain degree of literacy in Latin on the part of English Jews, and in Hebrew for at least a small number of Christians who had to deal with these documents. Adam Bishop has shown how the Latin Kingdom of Jerusalem established a justice system in which preference given to witnesses and accusers was calculated on an elaborate religious/ethnic hierarchy, with Latin Christians at the top, followed by Eastern Christians, Jews and Muslims. ${ }^{62}$ While legal theory often imposed distinct jurisdictions for religious minorities and for the majority, often there was considerable wiggle-room, and enough competition between jurisdictions, for the clever or lucky to be able to benefit from the situation: Katalin Szende gives examples for Hungarian Jews as does Filomena Barros for Portuguese Muslims. ${ }^{63}$ Ahmed Oulddali's case study of a Tlemcen Jew on trial for having insulted Muslims demonstrates how legal disputes between Muslims and dhimmis could generate complex legal problems which were taken quite seriously. ${ }^{64}$

These are just a few examples of the possibilities opened up by RELMIN's cross-disciplinary approach to the legal status of religious minorities. Inevitably, our research has raised as many or more questions than it has answered. It has led us to question the terminology we use to talk about these issues. To what extent can one call, say Syrian or Egyptian Christians of the ninth century a religious "minority « when they clearly outnumber Muslims? The very concepts of "law" and "religion « have been socially constructed in different ways in the diverse societies we have studied (and of course used in ways that do not correspond to

57 Serrano, Islamic Legal Jurisdiction over dhimmis.

58 Tolan, The Infidel before the Judge.

59 Lauer, Jewish Women in Venetian Candia.

60 Masset, L'intégration des juifs et des musulmans.

61 Olszowy-Schlanger, >Meet you in Court<.

62 Bishop, The Treatment of Minorities.

63 Szende, Laws, Loans, Literates; Barros, Les musulmans portugais.

64 Oulddali, Un dimmī accusé d’avoir calomnié les musulmans. 
our 21st-century use of these terms). ${ }^{65}$ RELMIN has put hundreds of texts online with translations and analyses and published over 10 volumes of conference acts and dissertations, but clearly has merely scratched the surface. Thanks to a major grant from the Pays de la Loire region in France, a new institute, the Institut du Pluralisme Religieux et de l'Athéisme (IPRA), has been created in Nantes: its mission is to continue the work of RELMIN and to broaden its scope by including the study of more recent periods in European history. ${ }^{66}$

65 Tolan, Lex alterius.

66 www.ipra.eu 


\section{References}

Aillet, Cyrille, La construction des frontières interconfessionnelles: le cas des chrétiens d'al-Andalus dans les sources juridiques (IIe/VIIIe-VIe/XIIe s.), in: Tolan and Fierro, The Legal Status of dimmi-s, 167-198.

Albert, Bat-Sheva, Les communautés juives vues à travers la législation royale et ecclésiastique visigothique et franque, in: Tolan et al., Jews in Early Christian Law, 179-193.

Augustine, De civitate Dei, ed. Bernardus Dombart and Alphonse Kalb, 2 vols, CCSL 47-48 (Turnhout, 1955).

Baumgarten, Elisheva, Christian Time in a Jewish Miscellany: A Hebrew Christian Calendar from Thirteenth Century Northern France, in: Tolan and Boissellier, Religious Cohabitation in European Towns, 169-83.

Bishop, Adam, The Treatment of Minorities in the Legal System of the Kingdom of Jerusalem, in: Capucine Nemo-Pekelman, John Tolan, Jerzy Mazur, Youna Masset (eds.), Medieval Minorities: Law and Multiconfessional Societies in the Middle Ages (Turnhout, 2016).

Bouchiba, Farid, Cohabitation religieuse et pratiques alimentaires à Cordoue au XIe-XIIe siècles d'après le grand Qāại Ibn Rušd Al-ğadd (M. 520/1126), in: Tolan and Boissellier, Religious Cohabitation in European Towns, 63-88.

Bouchiba, Farid, Eglises et synagogues en terre d'Islam au Moyen Âge : aspects sociaux et architecturaux. Que dit le droit musulman? (point de vue malikite), in: Capucine NemoPekelman, John Tolan, Jerzy Mazur, Youna Masset (eds.), Medieval Minorities: Law and Multiconfessional Societies in the Middle Ages (Turnhout, 2016) forthcoming.

Buc, Philippe, Keil, Martha and Tolan, John (eds.), Jews and Christians in Medieval Europe: The historiographical legacy of Bernhard Blumenkranz (Turnhout, 2015) forthcoming.

Carmona, Alfonso, Doctrina sobre la ğizya en el Occidente islámico pre-moderno, in: Tolan and Fierro, The Legal Status of dimmi-s, 91-110.

Catlos, Brian, Is It Country Air that Makes Infidels Free? Religious Diversity in the Non-Urban Environment of the Medieval Crown of Aragon and Beyond, in: Tolan and Boissellier, Religious Cohabitation in European Towns, 141-166.

Constable, Olivia Remie, From Hygiene to Heresy: Changing Perceptions of Women and Bathing in Medieval and Early Modern Iberia, in: Tolan and Boissellier, Religious Cohabitation in European Towns, 185-206.

Depreux, Philippe, Les juifs dans le droit carolingien, in: Tolan et al., Jews in Early Christian Law, 131-52.

Fattal, Antoine, Le statut légal des non-musulmans en pays d'Islam (Beirut, 1958).

Fierro, Maribel and Tolan, John V. (eds.), The Legal Status of dimmi-s in the Islamic West (second/eighth-ninth/fifteenth centuries), (Turnhout, 2013).

Fois, Luca, Physical Separation of Jews and Christians in Papal Legislation and the Legal Commentaries of Italian Jurists, in: Capucine Nemo-Pekelman, John Tolan, Jerzy Mazur, Youna Masset (eds.), Medieval Minorities: Law and Multiconfessional Societies in the Middle Ages (Turnhout, 2016) forthcoming.

Freidenreich, David M., Foreigners and their Food: Constructing Otherness in Jewish, Christian, and Islamic Law (Berkeley, 2011).

Heil, Johannes, Getting them in or Keeping them out? Theology, Law, and the Beginnings of Jewish Life at Mainz in the 10th and 11th centuries, in: Tolan et al., Jews in Early Christian Law, 211-228. 
Hernández López, Adday, La compraventa de vino entre musulmanes y cristianos dimmíes a través de textos jurídicos mālikíes del Occidente islámico medieval, in: Tolan and Fierro, The Legal Status of dimmi-s, 243-274.

Juster, Jean, Les Juifs dans l'Empire romain; leur condition juridique, économique et sociale (Paris, 1914).

Kriegel, Maurice, Mobilisation politique et modernisation organique. Les expulsions de Juifs au Bas Moyen Age, Archives de sciences sociales des religions 23/46.1 (1978) 5-20.

Lauer, Rena, Jewish Women in Venetian Candia: Negotiating Intercommunal Contact in a Premodern Colonial City, 1300-1500, in: Tolan and Boissellier, Religious Cohabitation in European Towns, 293-309.

Linder, Amnon, The Legal Status of the Jews in the Roman Empire, in: Steven Katz (ed.), The Cambridge History of Judaism. Volume IV, The Late Roman-Rabbinic Period (Cambridge, 2006) 128-173.

Lopes de Barros, Filomena, Les musulmans portugais: la justice entre la normativité chrétienne et la normativité islamique, in: Tolan and Boissellier, Religious Cohabitation in European Towns, 207-222.

Mansouri, Tahar, Les dhimmis dans les documents de chancellerie de l'époque mamelouke, in: Tolan and Boissellier, Religious Cohabitation in European Towns, 55-62.

Masset, Youna, L'intégration des juifs et des musulmans dans la ville de Tortose à travers l'étude de leur capacité processuelle (deuxième moitié du XIIIe siècle - premier quart du XIVe siècle), in: Tolan and Boissellier, Religious Cohabitation in European Towns, 273-291.

Mathisen, Ralph, The Citizenship and Legal Status of Jews in Roman Law during Late Antiquity (ca. 300-540 CE), in: Tolan et al., Jews in Early Christian Law, 35-53.

Molénat, Jean-Pierre, La fatwā sur la construction des églises à Cordoue au IVe/Xe siècle, in: Fierro and Tolan, The Legal Status of dimmi-s, 157-66.

Moukarzel, Pierre, La législation des autorités religieuses et politiques sur les marchands européens dans le sultanat mamelouk (1250-1517), in: Tolan and Boissellier, Religious Cohabitation in European Towns, 121-139.

Müller, Christian, Non-Muslims as Part of Islamic law: Juridical Casuistry in a Fifth/Eleventh Century Law Manual, in: Fierro and Tolan, The Legal Status of dimmi-s, 21-63.

Nef, Annliese, Le statut des dimmī-s dans la Sicile aghlabide (212/827-297/910), in: Fierro and Tolan, The Legal Status of dimmi-s, 111-29.

Nemo-Pekelman, Capucine, Rome et ses citoyens Juifs (IVe-Ve siècles), (Paris, 2010).

Olszowy-Schlanger, Judith, >Meet you in Court «: Legal Practices and Christian-Jewish Relations in the Middle Ages, in: Buc, Keil and Tolan (eds.), Jews and Christians in Medieval Europe, forthcoming.

Oulddali, Ahmed, Recevabilité du témoignage du dimmì d'après les juristes mālikites d'Afrique du Nord, in: Fierro and Tolan, The Legal Status of dimmi-s, 275-92.

Oulddali, Ahmed, Un dimmī accusé d'avoir calomnié les musulmans. Étude d'une fatwa rendue à Tlemcen en šawwāl 489/ janvier 1446, in: Tolan and Boissellier, Religious Cohabitation in European Towns, 225-241.

Paudice, Aleida, Religious Identity and Space in Venetian Candia: Segregation within Colonization, in: Tolan and Boissellier, Religious Cohabitation in European Towns, 91-107.

Rustow, Marina, The Legal Status of dimmi-s in the Fatimid East: A View from the Palace in Cairo, in: Fierro and Tolan, The Legal Status of dimmi-s, 307-32.

Sanjuán, Alejandro García, La formación de la doctrina legal mālikí sobre lugares de culto de los dimmíes, in: Tolan and Fierro, The Legal Status of dimmi-s, 131-56. 
Serrano, Delfina, Islamic Legal Jurisdiction over dhimmis and dhimmis Forum Shopping in al-Andalus: the Divergent Views of Malikis and Zahiris (10th-12th centuries C.E.), in: Capucine Nemo-Pekelman, John Tolan, Jerzy Mazur, Youna Masset (eds.), Medieval Minorities: Law and Multiconfessional Societies in the Middle Ages (Turnhout, 2016) forthcoming.

Soyer, François, Prohibiting Sexual Relations across Religious Boundaries in Fifteenth Century Portugal: Legal Severity and Practical Pragmatism, in: Capucine Nemo-Pekelman, John Tolan, Jerzy Mazur, Youna Masset (eds.), Medieval Minorities: Law and Multiconfessional Societies in the Middle Ages (Turnhout, 2016) forthcoming.

Stocking, Rachel, Forced Converts, »Crypto-Judaism, « and Children: Religious Identification in Visigothic Spain, in: Tolan et al., Jews in Early Christian Law, 243-65.

Szende, Katalin, Laws, Loans, Literates: Trust in Writing in the Context of Jewish-Christian Contacts in Medieval Hungary, in: Tolan and Boissellier, Religious Cohabitation in European Towns, 243-271.

Toch, Michael, The Jews in Europe, 500-1050, in: Paul Fouracre (ed.), The New Cambridge Medieval History I, c. 500- c.700 (Cambridge, 2005), 547-570, 871-877.

Toch, Michael, The Economic History of European Jews: Late Antiquity and Early Middle Ages (Leyden, 2012).

Tolan, John, The Infidel before the Judge: Navigating Justice Systems in Multiconfessional Medieval Europe, in: Dorothea Weltecke (ed.), Religiöse Vielfalt und der Umgang mit Minderheiten. Vergangene und gegenwärtige Erfahrungen (Konstanz, 2014) 57-79.

Tolan, John, Lex alterius: Using Law to Construct Confessional Boundaries, History and Anthropology 26 (2015) 1-21.

Tolan, John, Of Milk and Blood: Innocent III and the Jews, revisited, in: Elisheva Baumgarten and Judah Galinsky (eds.), Jews and Christians in Thirteenth-Century France (New York, 2015) 139-49.

Tolan, John V., Sons of Ishmael: Muslims through European Eyes in the Middle Ages (Gainesville, 2008) 147-160.

Tolan, John V. (ed.), Expulsion and Diaspora Formation: Religious and Ethnic Identities in Flux from Antiquity to the Seventeenth Century (Turnhout, 2015).

Tolan, John V. and Boissellier, Stéphane (eds.), Religious Cohabitation in European Towns (10th15 th centuries)/La cohabitation religieuse dans les villes Européennes, Xe-XVe siècles, Religion and Law in Medieval Christian and Muslim Societies 3 (Turnhout, 2014).

Tolan, John V., de Lange, Nicolas, Foschia, Laurence, Nemo-Pekelman, Capucine (eds.), Jews in Early Christian Law: Byzantium and the Latin West, 6th-11th centuries, Religion and Law in Medieval Christian and Muslim Societies 2 (Turnhout, 2013).

Valérian, Dominique, Les marchands musulmans dans les ports chrétiens au Moyen Âge, in: Tolan and Boissellier, Religious Cohabitation in European Towns, 109-120.

Voguet, Elise, Les communautés juives du Maghreb central à la lumière des fatwa-s mālikites de la fin du Moyen Âge, in: Fierro and Tolan, The Legal Status of dimmi-s, 295-306. 